\title{
Вплив занять за комплексною програмою фізичної реабілітації на біоелектричну активність серця юнаків, хворих на бронхіальну астму
}

\author{
Юрій Фурман \\ Вікторія Онищук, \\ Наталія Гаврилова \\ Здебський Олександр
}

\author{
Вінницький державний педагогічний університет імені \\ Михайла Кочюбинського, Вінниця, Україна
}

Протягом останнього десятиліття медична статистика констатує неухильне зростання бронхіальної астми (БА) серед осіб різного віку. В Україні серед дітей віком 6 - 7 років бронхіальна астма простежується у 8,1\%; віком 16-18 років 6,1\%. Такий відсоток захворюваності серед молодого населення $є$ не лише медико-біологічною, але й соціальною проблемою, оскільки створює перешкоди для одержання освіти й обмежує в подальшому можливості вибору профресії. Варто відзначити, що поширення захворюваності на БА супроводжується ускладненням перебігу зазначеної хвороби. Відомо, що у осіб з бронхіальною астмою часто виникають порушення діяльності фрункції серцево-судинної системи. У таких осіб простежується синусова тахікардія більш як 120 скорочень в 1 хвилину, підвищення артеріального тиску, наростання клінічних ознак правошлуночкової недостатності (набухання шийних вен, збільшення печінки). На електрокардіограмі визначаються ознаки перевантаження правих відділів серця. Такі наслідки викликають занепокоєння, що в подальшому може призвести до інвалідності та смертності. Для покращення стану хворих на бронхіальну астму використовують різноманітні засоби фрізичної реабілітації. Однак, застосування традиційних методів і засобів фрізичної реабілітації не завжди є ефрективним для хворих, що підтверджується зростанням захворюваність серед осіб молодого віку. Класичні засоби фрізичної реабілітації застосовують головним чином у санаторно-лікувальних та диспансерних закладах, що робить їх недоступними для молоді у період навчання через брак часу. 3 огляду на це постає проблема пошуку і розробки наближених до процесу навчання нових ефективних технологій фрізичної реабілітації молоді, яка хворіє на бронхіальну астму.

Мета: обгрунтувати та розробити комплексну програму фрізичної реабілітації юнаків, хворих на бронхіальну астму. Матеріал і методи: Для вирішення поставлених завдань використовувалися такі методи дослідження: огляд літературних джерел; електрокардіографрія, сфрігмоманометрія; методи математичної статистики.

Результати. Заняття за розробленою програмою, яка включала дихальну гімнастику на апараті «Ендогенік $01 »$, не викликали негативних змін біоелектричної активності серия у юнаків. Результати наших досліджень засвідчили, що під впливом систематичних занять у студентів основної групи вже через 30 тижнів збільшується тривалість інтервалу $R$ - $R$ на 3,67\% ( $p<0,05)$. При цьому відповідно відбувається зменшення частоти серцевих скорочень на 3,18\% $(p<0,05)$. По завершенню курсу фізичної реабілітації нами зареєстроване подальше збільшення інтервалу $R-R($ на $3,79 \%, p<0,05)$ у студентів основної групи. Частота серцевих скорочень у юнаків на $3,42 \%(p<0,02)$ залишилась вірогідно низькою порівняно зі значеннями, зареєстрованими до початку формувального експерименту. Решта досліджуваних показників біоелектричної активності серия у юнаків основної групи протягом 40 тижнів занять суттєво не змінилась. Нами не зареєстровано в студентів даної групи вірогідних змін артеріального тиску протягом сорокатижневого періоду занять. Висновки. Заняття за розробленою програмою не викликали негативних змін біоелектричної активності серця у юнаків. При цьому слід відзначити як позитивний френомен вірогідне зниження частоти серцевих скорочень, що свідчить про економізацію серцевої діяльності досліджуваних в стані відносного м'язового спокою.

Ключові слова: студенти, бронхіальна астма, фрізична реабілітація.

\section{Вступ}

Протягом останнього десятиліття медична статистика констатує неухильне зростання бронхіальної астми (БА) серед осіб різного віку. Кількість хворих на бронхіальну астму у світі коливається в середньому в межах від 4 до $8 \%$, а серед молоді - від 2 - $15 \%$ [2, 5, с.172]. Особливо тривожним $€$ розповсюдженість бронхіальної астми серед осіб молодого віку. В Україні серед дітей віком 6 - 7 років бронхіальна астма простежується у $8,1 \%$; віком 16-18 років - 6,1\% [3, 4]. Такий відсоток захворюваності серед молодого населення $є$ не лише медико-біологічною, але й соціальною проблемою, оскільки створює перешкоди для одержання освіти й обмежує в подальшому можливості вибору професії [12, с. 2563 с.177]

За даними Ю.М. Мостового (2013) у Вінницькій облас- ті кількість хворих на БА, які отримують інвалідність, кожного року зростає приблизно на 100 осіб. Так, у м. Вінниці здійснюється близько чотирьох тисяч викликів швидкої допомоги для зняття нападу БА, що складає в середньому 4\% від усіх викликів. Варто відзначити, що поширення захворюваності на БА супроводжується ускладненням перебігу зазначеної хвороби [3. 48-49; 4, с.31; 13 с.746].

Відомо, що у осіб з бронхіальною астмою часто виникають порушення діяльності функції серцево-судинної системи [9, с. 115-116]. У таких осіб простежується синусова тахікардія більш як 120 скорочень в 1 хвилину, підвищення артеріального тиску, наростання клінічних ознак правошлуночкової недостатності (набухання шийних вен, збільшення печінки). На електрокардіограмі визначаються ознаки перевантаження правих відділів серця. Такі наслідки викликають занепокоєння, що в подальшому може 


\section{Матеріали XIX Міжнародної науково-практичної конференції «Фізична культура, спорт і здоров'я: стан, проблеми та перспективи»}

призвести до інвалідності та смертності. В Україні в 2013 році первинно визнані інвалідами внаслідок захворювання на бронхіальну астму 2480 чоловік працездатного віку. Наслідки такої невпинної розповсюдженості БА в Україні обумовлені впливом шкідливих чинників навколишнього середовища, вживанням низькоякісних харчових добавок, використанням хімічних засобів у побуті, нераціональним харчуванням, безсистемним вживанням медикаментів, активним і пасивним палінням, стресовими впливами, а також недостатньою руховою активністю [ 1 с. $12 ; 2$ с. $99 ; 11$, с. $176 ; 12$, с. 2564$]$.

Для покращення стану хворих на бронхіальну астму використовують різноманітні засоби фрізичної реабілітації. Однак, застосування традиційних методів і засобів фрізичної реабілітації не завжди є ефективним для хворих, що підтверджується зростанням захворюваність серед осіб молодого віку. Класичні засоби фізичної реабілітації застосовують головним чином у санаторно-лікувальних та диспансерних закладах, що робить їх недоступними для молоді у період навчання через брак часу. 3 огляду на це постає проблема пошуку і розробки наближених до процесу навчання нових ефективних технологій фрізичної реабілітації молоді, яка хворіє на бронхіальну астму.

Мета дослідження: обґрунтувати та розробити комплексну програму фрізичної реабілітації юнаків, хворих на бронхіальну астму та перевірити іі вплив на біоелектричну активність серця.

Для досягнення мети вирішували такі завдання:

1. Вивчити й узагальнити стан питання з даної проблеми.

2. Скласти комплексну програму фрізичної реабілітації для юнаків, хворих на бронхіальну астму.

3. Оцінити ефективність впливу занять за розробленою програмою на показники біоелектричної активності серця й артеріальний тиск юнаків, хворих на бронхіальну астму.

\section{Матеріал і методидослідження}

Для вирішення поставлених завдань використовували наступні методи: огляд літературних джерел; для реєстрації біоелектричної активності серця використовувався електрокардіографр «ЭКПСЧТ - 4». При цьому застосовували відведення $\mathrm{H}_{2}$ за Небом. Запис електрокардіограми (ЕКГ) здійснювали в стані відносного м'язового спокою в положенні сидячи. При аналізі ЕКГ враховували такі показники:

- тривалість інтервалу R-R, який відображає частоту i ритм серцевих скорочень і вимірюється в секундах (одне ділення на стрічці по горизонталі відповідає 0,02 c);

- тривалість інтервалу $\mathrm{P}-\mathrm{Q}$, який характеризує передсердно-шлуночкову провідність і відповідає часу проведення імпульсу від синусового вузла по пучку Гіса до волокон Пуркіньє (нормальна тривалість у стані спокою $0,11-0,18 \mathrm{c})$;

- тривалість інтервалу Q-Т, яка відповідає тривалості електричної систоли (нормальна тривалість у стані спокою $0,35-0,45 \mathrm{c})$;

- висота зубця Р, яка характеризує біоелектричні процеси, що виникають під час збудження передсердь (нормальна величина у стані спокою 0,5-2,5 мм);

- висота зубця $\mathrm{R}$, яка відображає ступінь деполяризації міокарду (нормальна величина у стані спокою 6-16 мм);
- висота зубця Т, яка відображає залишкове збудження повільних м'язових волокон шлуночків (нормальна величина у стані спокою 2,5-6,0 мм).

Артеріальний тиск у стані відносного м'язового спокою вимірювали за допомогою сфігмоманометра «LD$91 »$.

Статистичну обробку отриманих показників проводили за t-критерієм Стьюдента.

В обстеженні взяли участь юнаки віком 17-19 років, які за станом здоров'я були віднесені до спеціальноїмедичної групи Вінницького державного педагогічного університету ім. Михайла Коцюбинського. У дослідженні взяли участь 23 юнаки у яких діагностували інтермітуючу та легку персистуючу бронхіальну астму. Всі досліджувані були розподіленні на дві групи: контрольну (КГ), що складалася із 12 юнаків, та основну (ОГ) - 11 юнаків.

Юнаки контрольної групи займалися за типовою програмою з лікувальної фрізичної культури для хворих на бронхіальну астму. До змісту програми входили: статичні та динамічні дихальні вправи з повільним, подовженим видихом; звукова гімнастика; дренажні вправи; елементи спортивних ігор; ходьба. Вправи виконувалися в середньому темпі, кожна вправа повторювалась 8-12 разів, усе заняття з лікувальної гімнастики тривало 30-35 хв.

Юнаки основної групи займалися за розробленою авторською програмою фізичної реабілітації. Курс лікувальної фізичної культури умовно ділили на три періоди: підготовчий, тренувальний і підтримуючий. Тривалість усього курсу фрізичної реабілітації для студентів контрольної та основної груп становила 40 тижнів.

Під час вступного періоду реабілітації юнаки основної групи навчалися регулювати тривалість фаз вдиху і видиху, засвоювали техніку дихальних вправ з вимовлянням звуків на видиху, техніку діафрагмального типу дихання, та аутогенне тренування за класичною методикою Шульца. Самостійно вранці юнаки робили ранкову гігієнічну гімнастику (РГГ), після якої застосовували теплий душ, який завершувався одномоментним обливанням холодною водою. Руховий режим - щадний.

Протягом основного періоду реабілітації поряд зі спеціальними дихальними вправами широко використовували такі гімнастичні вправи як: згинання, розгинання, відведення, приведення та обертання кінцівок; розгинання, нахили вперед і в сторони тулуба. Під час виконання цих вправ увага акцентувалась на повільний тривалий видих. Восени, навесні та влітку використовували дозовані біг та ходьбу по біговій доріжці стадіону, ходьбу і біг сходами вгору з високим підніманням стегна та ходьбу через бар'єри. Значну увагу приділяли вправам з високим підніманням стегна під час ходьби сходами вгору, що сприяло виведенню мокроти з бронхів. Для посилення дренажного ефекту ми долучили до програми ходьбу через бар'єри. Через те, що висота планки бар'єра вища, ніж сходинки пацієнт вимушений високо піднімати стегно, що покращувало виведення з бронхів мокротиння в момент піднімання стегна. При цьому особлива увага зосереджувалася на фразі видиху. Вправи виконували у середньому темпі.

Разом з цим студенти основної групи займалися дихальною гімнастикою на апараті «Ендогенік 01». Саме дихання через апарат «Ендогенік 01» створює в організмі стан помірної гіпоксії і вираженої гіперкапнії. Вміст кисню в повітрі, яке вдихається через даний пристрій, зменшується усього в 1,1 рази, а вуглекислого газу збільшується у 100 разів [7, с.172]. Таке співвідношення газів уапараті 


\section{СЛОБОЖАНСЬКИЙ НАУКОВО-СПОРТИВНИЙ ВІСНИК:}

\section{Матеріали XIX Міжнародної науково-практичної конференції «Фізична культура, спорт і здоров'я: стан, проблеми та перспективи»}

утримується протягом усієї процедури. Посиленню гіперкапнії сприяє також тривалий рівномірний видих, під час якого уповільнюється дифузія вуглекислого газу з легень. Разом з тим опір проходження повітря під час видиху збільшує внутрібронхіальний тиск, який механічно розширює бронхи внаслідок чого покращується їх пропускна спроможність [10, с. 2569-2572; 11, с.177]. Обмеження постачання організму киснем викликає поступове підвищення ефективності легеневої вентиляції, збільшення альвеолярної мережі капілярів легень та покращення дифузії газів через альвеолярно- капілярний бар'єр, що сприяє зростанню оксигенації артеріальної крові [6, 9, 10, 11]. Руховий режим щадно - тренувальний.

У підтримуючому періоді реабілітації юнаки продовжували застосовувати ранкову гігієнічну гімнастику, дихальну гімнастику на апараті «Ендогенік 01 », одномоментне обливання холодною водою після теплого душу та лікувальну гімнастику, яка включала дихальні вправи, дозований біг та ходьбу по біговій доріжці, ходьбу і біг сходами вгору та ходьбу через бар'єри, аутогенне тренування.

Кожне заняття з лікувальної гімнастики (40-45 хв), незалежно від періоду реабілітації, складалося з трьох частин: підготовчої, основної та заключної. У підготовчій частині заняття тривалістю 7-10 хвилин, юнаки застосовували спеціальні дихальні вправи. В основній частині заняття поряд зі спеціальними дихальними вправами використовували загальнорозвивальні гімнастичні вправи. Тривалість основної частини заняття складала 25-30 хвилин. У заключній частині заняття використовувалися дихальні вправи і вправи на розслаблення м'язів. Тривалість заключної частини коливалась від 5 до 8 хвилин. Дозування фізичного навантаження залежало від поставлених завдань, періоду фізичної реабілітації, особливостей перебігу хвороби, функціональних можливостей організму юнаків. Дозування здійснювалося за рахунок варіації вихідних положень, ступеня складності вправ, збільшення або зменшення амплітуди рухів та кількості повторень.

У період навчання юнаки займалися за розробленою комплексною програмою два рази на тиждень згідно 3 розкладом занять з фрізичного виховання і додатково один раз на тиждень у позанавчальний час під контролем фахівця з фізичної реабілітації. Заняття за розробленою про-

Таблиця 1

Показники ЕКГ, артеріального тиску, ЧСС у стані відносного м'язового спокою юнаків 17 -19 років контрольної та основної груп

\begin{tabular}{|c|c|c|c|c|c|c|c|c|c|c|}
\hline \multirow[b]{2}{*}{ Показники } & \multicolumn{10}{|c|}{ Значення показників } \\
\hline & \multicolumn{2}{|c|}{ до початку занять } & \multicolumn{2}{|c|}{$\begin{array}{c}\text { через } 10 \\
\text { тижнів від початку } \\
\text { занять }\end{array}$} & \multicolumn{2}{|c|}{$\begin{array}{c}\text { через } 20 \text { тижнів від } \\
\text { початку } \\
\text { занять }\end{array}$} & \multicolumn{2}{|c|}{$\begin{array}{c}\text { через } 30 \\
\text { тижнів від початку } \\
\text { занять }\end{array}$} & \multicolumn{2}{|c|}{$\begin{array}{c}\text { через } 40 \\
\text { тижнів від початку } \\
\text { занять }\end{array}$} \\
\hline \multicolumn{11}{|c|}{ контрольна група $(\mathrm{n}=12)$} \\
\hline$P-Q, C$ & 0,128 & 0,0029 & 0,123 & 0,0029 & 0,1245 & 0,0029 & 0,1245 & 0,0039 & 0,1254 & 0,0039 \\
\hline $\mathrm{R}-\mathrm{R}, \mathrm{c}$ & 0,816 & 0,0099 & 0,815 & 0,0099 & 0,816 & 0,0039 & 0,8218 & 0,0079 & 0,8245 & 0,0079 \\
\hline Q-T, c & 0,333 & 0,0022 & 0,330 & 0,0049 & 0,3318 & 0,0049 & 0,337 & 0,0019 & 0,337 & 0,0019 \\
\hline $\begin{array}{l}\text { Вольтаж } \\
\text { зубця Р, мм }\end{array}$ & 1,281 & 0,0399 & 1,281 & 0,0399 & 1,263 & 0,0399 & 1,272 & 0,0399 & 1,272 & 0,0399 \\
\hline $\begin{array}{l}\text { Вольтаж } \\
\text { зубця R, мм }\end{array}$ & 13,6 & 0,3993 & 13,72 & 0,399 & 13,72 & 0,399 & 13,818 & 0,399 & 13,818 & 0,399 \\
\hline $\begin{array}{l}\text { Вольтаж } \\
\text { зубця Т, мм }\end{array}$ & 3,954 & 0,2196 & 3,954 & 0,1996 & 3,972 & 0,1996 & 3,972 & 0,1896 & 3,990 & 0,1896 \\
\hline \multirow{2}{*}{$\begin{array}{l}\text { АТ, мм рт.ст. } \\
\text { систолічний } \\
\text { діастолічний }\end{array}$} & 115 & 0,998 & 115,45 & 0,991 & 115,45 & 0,988 & 114,54 & 1,497 & 114,09 & 1,497 \\
\hline & 73,18 & 1,99 & 71,84 & 1,906 & 70 & 1,497 & 70 & 1,996 & 69,54 & 1,9965 \\
\hline ЧСС, уд хв ${ }^{-1}$ & 73,45 & 0,898 & 73,46 & 0,7806 & 73,36 & 0,798 & 73,00 & 0,698 & 72,63 & 0,698 \\
\hline \multicolumn{11}{|c|}{ основна група $(\mathrm{n}=11)$} \\
\hline$P-Q, C$ & 0,128 & 0,0027 & 0,130 & 0,0018 & 0,1341 & 0,0018 & 0,135 & 0,0027 & 0,1383 & 0,0018 \\
\hline$R-R, c$ & 0,79 & 0,007 & 0,81 & 0,0074 & 0,80 & 0,0074 & 0,819 & $0,0074^{*}$ & 0,82 & $0,0064^{* *}$ \\
\hline Q-T, c & 0,333 & 0,0018 & 0,331 & 0,0018 & 0,333 & 0,0018 & 0,336 & 0,0009 & 0,336 & 0,0009 \\
\hline $\begin{array}{l}\text { Вольтаж } \\
\text { зубця Р, мм }\end{array}$ & 1,258 & 0,037 & 1,241 & 0,037 & 1,258 & 0,037 & 1,258 & 0,037 & 1,241 & 0,037 \\
\hline $\begin{array}{l}\text { Вольтаж } \\
\text { зубця R, мм }\end{array}$ & 13,0 & 0,278 & 13,083 & 0,278 & 13,16 & 0,278 & 13,166 & 0,27 & 13,416 & 0,278 \\
\hline $\begin{array}{l}\text { Вольтаж } \\
\text { зубця Т, мм }\end{array}$ & 3,616 & 0,203 & 3,725 & 0,1996 & 3,783 & 0,2316 & 3,816 & 0,231 & 3,85 & 0,2224 \\
\hline \multirow{2}{*}{$\begin{array}{l}\text { АТ, мм рт.ст. } \\
\text { систолічний } \\
\text { діастолічний }\end{array}$} & 118,75 & 1,85 & 118,3 & 1,85 & 118,3 & 1,853 & 116,25 & 1,85 & 116,66 & 1,390 \\
\hline & 78,75 & 1,85 & 75 & 1,854 & 75 & 1,854 & 74,58 & 1,3900 & 74,58 & 1,3900 \\
\hline ЧСС, уд хв-1 & 75,41 & 0,64 & 74,08 & 0,648 & 74,08 & 0,741 & 73,08 & $0,7413^{*}$ & 72,833 & $0,648^{* *}$ \\
\hline
\end{tabular}

Примітки. вірогідної відмінності значень відносно величин, зареєстрованих до початку занять: * $-p<0,05$; 


\section{Матеріали XIX Міжнародної науково-практичної конференції «Фізична культура, спорт і здоров'я: стан, проблеми та перспективи»}

грамою проводили груповим методом.

Під час зимових канікул (щоденно) та вихідних днів юнаки самостійно займалися ранковою гігієнічною гімнастикою, одномоментним обливанням холодною водою після теплого душу, а також застосовували аутогенне тренування за класичною методикою Шульца.

\section{Результати дослідження}

3 метою раннього виявлення можливого негативного впливу занять за розробленою програмою фрізичної реабілітації на серцево-судинну систему нами досліджувалася біоелектрична активність серця, а також артеріальний тиск через кожні 10 тижнів від початку занять у студентів контрольних та основнихгруп.

Варто зауважити, що у юнаків контрольної групи середні показники біоелектричної активності серця, частоти серцевих скорочень, систолічного та діастолічного артеріального тисків у стані відносного м'язового спокою протягом 40 тижнів, не зазнали суттєвих змін, що підтверджується результатами у таблиці 1.

Під впливом систематичних занять у студентів основної групи через 30 тижнів збільшується тривалість інтервалу R-R на 3,67\% ( $<0,05)$. При цьому відповідно відбувається зменшення частоти серцевих скорочень на $3,18 \%$ $(p<0,05)$. Серед решти показників електрокардіографії, систолічного і діастолічного артеріального тисків у юнаків основної групи протягом 30 тижнів занять за розробленою програмою, вірогідних змін не виявлено.

По завершенню курсу фрізичної реабілітації нами зареєстроване подальше збільшення інтервалу R-R у студентів основної групи. У юнаків інтервал R-R перевищував вихідне значення на $3,79 \%(p<0,05)$. Залишилась вірогідно низькою порівняно зі значеннями, зареєстрованими до початку формувального експерименту частота серцевих скорочень на $3,42 \%(p<0,02)$.

Решта досліджуваних показників біоелектричної активності серця у юнаків основної групи протягом 40 тижнів занять суттєво не змінились. Нами також не зареєстровано у студентів цих груп вірогідних змін артеріального тис- ку протягом сорокатижневого періоду занять.

Отже проведені заняття за розробленою програмою фрізичної реабілітації, яка крім лікувальної фрізичної культури включала ранкову гігієнічну гімнастику, аутогенне тренування, дихальну гімнастику на апараті «Ендогенік $01 »$, вправи з високим підніманням стегна, одномоментне обливання холодною водою після теплого душу, не викликали негативних змін біоелектричної активності серця. При цьому вірогідно збільшився інтервал R-R і відповідно зменшилась частота серцевих скорочень, що розцінюється як позитивне явище, оскільки свідчить про економізацію серцевої діяльності в стані відносного м'язового спокою.

\section{Висновки /Дискусія}

1. Узагальнення науково-методичної інформації 3 теми дослідження показало, що незалежно від віку простежується щорічна динаміка розповсюдженості бронхіальної астми.

2. Відповідно до наукових відомостей з пробле-ми застосування засобів фрізичної реабілітації хворих на бронхіальну астму створено і апробовано комплексну програму для студентів ВНЗ з даною хворобою. Особливістю запропонованої програми $€$ те, що в комплексі зі спеціальними фізичними вправами використовувалася дихальна гімнастика на апараті «Ендогінік $01 »$.

3. Заняття за розробленою програмою не викликали негативних змін біоелектричної активності серця у юнаків. При цьому слід відзначити як позитивний френомен вірогідне зниження частоти серцевихскорочень, що свідчить про економізацію серцевої діяльності досліджуваних в стані відносного м'язового спокою.

Перспектива подальших досліджень. Перспектива подальших досліджень полягає у вдосконаленні програм фрізичної реабілітації, які б включали методи- ку створення в організмі стану помірної гіпоксії і ви- раженої гіперкапнії з урахуванням віку, статі та рівня фрізичного і функціонального стану осіб з бронхіальною астмою.

Конфлікт інтересів. Автори заявляють, що немає конфлікту інтересів, який може сприйматися таким, що може нанести шкоду неупередженості статті. Джерела фінансування. Ця стаття не отримала фінансової підтримки від державної, громадської або комерційної організації.

\section{Список посилань}

$\overline{\text { 1. Альошина, А. I . (2012), "Особливості застосування лікувальної фрізичної культури для дітей хворих на бронхіальну астму", Педагогіка, }}$ психологія та медико-біологічні проблеми фрізичного виховання і спорту, № 6, С. 12-15.

2. Григус, І. М. (2011), "Відновлення функціонального стану хворих на інтермітуючу бронхіальну астму засобами фрізичної реабілітації", Спортивна наука України, №2, С.98-104

3. Ковальчук, М.П.(1998), "Епідеміологічні дослідження бронхіальної астми у дітей", ПАГ, №2, С. 48-49.

4. Мостовий, Ю. М. (2011), "Бронхіальна астма, ХОЗЛ та серцево-судинні захворювання", Здоров'я України, № 3, С. 30-31.

5. Мостовий, Ю. М. (2008), Сучасні класифікації та стандарти лікування розповсюджених захворювань внутрішніх органів, за ред. д-ра мед. наук, проф. Ю.М. Мостового, 10-е. вид., доп. і перероб., Вінниця, С. 30-53.

6. Онищук, В. Є. (2010), "Терміновий вплив «ендогенно-гіпоксичного» дихання на показники спірографії у хворих на бронхіальну астму", Молода спортивна наука України: зб. наук. праць з галузі фріз. культури та спорту, № 14, Т.3, С. 145-150.

7. Онищук, В. Є. (2011), "Фізична реабілітація студентів, хворих на бронхіальну астму шляхом комплексного застосування методики «ендогенно-гіпоксичного» дихання та циклічних вправ аеробного спрямування", Молода спортивна наука України: зб. наук. праць з галузі фріз. культури та спорту, №. 15, Т.3, С.171-177.

8. Фурман, Ю. М., Онищук, В. Є. (2010), "Ефективність застосування методики «ендогенно-гіпоксичного» дихання за показниками спірографії в системі фрізичної реабілітації студенток, хворих на бронхіальну астму", Фізична культура, спорт та здоров’я нації, Вінниця, № 10, С. $101-107$.

9. Дьомкіна, Т., Онищук, В. (2015), "Експрес-вплив ендогенно-гіпоксичного дихання на показники артеріального тиску та спірографії студенток, хворих на нейроциркуляторну дистонію", Physical Education, Sports and Health Culture in Modern Society, № 2(30), C. 114-118.

10. Gavrylova, Nataliia, Bohuslavska, Viktoriia, Pityn, Maryan, Moseichuk, Yuriy, (2017), "Effectiveness of the application of the endogenoushypoxic breathing technique in the physical training of 13-16-year-old cyclists", Journal of Physical Education and Sport, Art 291 , pp. $2568-2575$. 11. Galandzovskyi, S., Onyshchuk, V. (2017), "Improvement of Respiratory System Performance Among the Students of Transport College by Means of Running Exercises and the Method of Endogenous Hypoxic Respiration", Physical Education, Sports and Health Culture in Modern Society, № (2(38), pp. 75-79. 


\section{СЛОБОЖАНСЬКИЙ НАУКОВО-СПОРТИВНИЙ ВІСНИК:}

\section{Матеріали XIX Міжнародної науково-практичної конференції «Фізична культура, спорт і здоров'я: стан, проблеми та перспективи»}

12. Onyshchuk, V., Bohuslavska, Viktoriia, Pityn, Maryan, Kyselytsia, Oksana (2017), "Substantiation of the integrated physical rehabilitation program for the higher educational establishment students suffering from bronchial asthma", Journal of Physical Education and Sport, № 17(4), Art 290, pp. $2561-2567$.

13. Webb, W. R. (1994), "High-resolution computed tomography of obstructive lung disease", Radiol. Clin. North. Amer, V.32, № 3, pp. 745757.

Стаття надійшла до редакції: 11.11.2019 р.

Опубліковано: 30.12.2019 p.

Аннотация. Фурман Юрий Николаевич, Онищук Виктория Евгеньевна, Гаврилова Наталья Владимировна, Здебской Александр Олегович. Влияние занятий по комплексной программе физической реабилитации на биоэлектрическою активность сердца юношей больных бронхиальной астмой. В течение последнего десятилетия медицинская статистика констатирует неуклонный рост бронхиальной астмы (БА) среди лиц разного возраста. В Украине среди детей 6 - 7 лет бронхиальная астма прослеживается в 8,1\%; в возрасте 16-18 лет - 6,1\%. Такой процент заболеваемости среди молодого населения является не только медико-биологической, но и социальной проблемой, поскольку создает препятствия для получения образования и ограничивает в дальнейшем возможности выбора профеессии. Cтоит отметить, что распространение заболеваемости БА сопровождается ослож- нением течения указанной болезни. Известно, что улии с бронхиальной астмой часто возникают нарушения деятельности фрункции сердечно-сосудистой системы. У таких лиц прослеживается синусовая тахикардия более 120 сокращений в 1 минуту, повышение артериального давления, нарастание клинических признаков правожелудочковой недостаточности (набухание шейных вен, увеличение печени). На электрокардиограмме определяются признаки перегрузки правых отделов сердиа. Такие последствия вызывают беспокойство, что в дальнейшем может привести к инвалидности и смертности. Для улучшения состояния больных бронхиальной астмой используют различные средства фризической реабилитации. Однако, применение традиционных методов и средств физической реабилитации не всегда является эфффективным для больных, что подтверждается ростом заболеваемости среди лии молодого возраста. Классические средства физической реабилитации применяют главным образом в санаторно-лечебных и диспансерных учреждениях, делает их недоступными для молодежи в период обучения за нехватки времени. С этим возникает проблема поиска и разработки приближенных к процессу обучения новых эфрфективных технологий фризической реабилитации молодежи, который болеет бронхиальной астмой. Цель работы обосновать и разработать комплексную программу физической реабилитации юношей, больных бронхиальной астмой. Методы исследования. Для решения поставленных задач использовались следующие методы исследования: обзор литературных источников; электрокардиография, сфригмоманометрия; методы математической статисти- ки. Результаты. Занятия по разработанной программе, которая включала дыхательную гимнастику на аппарате «Эндогеник 01», не вызывали негативных изменений биоэлектрической активности сердиа у юношей. Результаты наших исследований показали, что под влиянием систематических занятий у студентов основной группы уже через 30 недель увеличивается продолжительность интервала $R-R$ на $3,67 \%$ (p <0,05). При этом в соответствии происходит уменьшение частоты сердечных сокращений на $3,18 \%(p<0,05)$. По завершению курса ффизической реабилитации нами зарегистрировано дальнейшее увеличение интервала $R-R($ на $3,79 \%, p<0,05)$ у студентов основной группы. Частота сердечных сокращений у юношей на $3,42 \%(p<0,02)$ осталась достоверно ниже по сравнению со значениями, зарегистрированными до начала сормирующего эксперимента. Остальные исследуемых показателей биоэлектрической активности сердиа у юношей основной группы в течение 40 недель занятий существенно не изменилась. Нами не зарегистрировано у студентов данной группы достоверных изменений артериального давления в течение сорокатижневого периода занятий. Выводы. Занятия по разработанной программе не вызывали негативных изменений биоэлектрической активности сердиа уюношей. При этом следует отметить как положительный фьеномен достоверное снижение частоты сердечных сокращений, свидетельствует об экономизации сердечной деятельности исследуемых в состоянии относительного мышечного покоя.

Ключевые слова: студенты, бронхиальная астма, физическая реабилитация.

Abstract. Furman Yuriy, Onishchuk Victoria, Gavrilova Natalya, Zdebski Alexandr. The influence of occupations on the complex program of physical rehabilitation on the bioelectric activity of heart of adolescents with bronchial asthma. Over the last decade medical statistics have shown a steady increase of bronchial asthma among people of all ages. In Ukraine, 8, 1\% of 6-7 years old children have bronchial asthma; at the age of 16-18 years - 6.1\%. This percentage of morbidity among young people is not only a biomedical, but also a social problem, as it creates obstacles in education and further restricts the opportunity to choose a profession. It is worth noticing, that the prevalence of asthma is accompanied by a complication of the disease. It is known that people with bronchial asthma often have abnormalities of the cardiovascular function. Such people are inclined to have sinus tachycardia with more than 120 contractions in 1 minute, an increase in blood pressure, an increase in clinical signs of right ventricular insufficiency (swelling of the cervical veins, enlargement of the liver). With the help of an electrocardiogram the signs of an overload of right departments of heart are determined. Such consequences cause concerns, which further can lead to disability and mortality. Various means of physical rehabilitation are used to improve the condition of patients with bronchial asthma. However, the use of traditional methods and means of physical rehabilitation are not always effective for patients, as evidenced by the increase in the incidence rate among young people. Classical means of physical rehabilitation are used mainly in sanatorium-medical and dispensary establishments, which makes them inaccessible for young people during the period of studying, because they are run out of time. These facts raise the problem of finding and developing new effective technologies for the physical rehabilitation of young people suffering from bronchial asthma. The purpose of the work is to substantiate and develop a comprehensive program of physical rehabilitation of adolescents with bronchial asthma. Research methods. The following research methods were used to solve these tasks: review of literary sources; electrocardiography, sphygmomanometry; methods of mathematical statistics. Results. The developed program exercises, which included respiratory gymnastics on the apparatus "Endogenic 01", did not cause negative changes in the bioelectric activity of the adolescents' hearts. The results of our studies showed that under the influence of systematic classes in students of the main group, after 30 weeks, the duration of the R-R interval increased by $3,67 \%(p \& 1 t ; 0,05)$. In this case, the heart rate is reduced by $3,18 \%(p \& l t ; 0,05)$. After completing the course of physical rehabilitation, we registered a furtherincrease in the $R$-R interval (by $3,79 \%, p \& 1 t ; 0,05)$ in the students of the main group. The heart rate in adolescents by $3,42 \%(p \&$ \&tt;0,02) remained significantly lower compared to the values recorded prior to the formation of the experiment. The rest of the studied indicators of adolescents heart's bioelectric activity did not change significantly during the 40 weeks of training. We have not registered any significant changes in blood pressure in the students of this group during the 40-week training period. Conclusions. Classes of the developed program did not cause negative changes in the bioelectric activity of the heart in adolescents. At the same time, it should be noted as a positive phenomenon that a reliable decrease in heart rate indicates the economization of cardiac activity of the subjects studied in a state of a relative muscle rest.

Keywords: students, bronchial asthma, physical rehabilitation. 


\section{Матеріали XIX Міжнародної науково-практичної конференції «Фізична культура, спорт і здоров'я: стан, проблеми та перспективи»}

\section{References}

1. Alyoshina A.I. (2012), "Features of the use of therapeutic physical culture for children with bronchial asthma", Pedagogics, psychology and medical and biological problems of physical education and sport of sports, No 6, pp. 12-15.

2. Grigus I.M (2011), "Restoration of the functional state of patients with intermittent bronchial asthma by means of physical rehabilitation ", Sports Science of Ukraine, No 2, pp.98-104.

3. Kovalchuk M.P. (1998), "Epidemiological studies of bronchial asthma in children", PAG. No 2, pp. 48-49. 4.Mostovy Yu.M. (2011), "Bronchial asthma, COPD and cardiovascular disease", Health of Ukraine, No 3, pp. 30-31.

5. Mostovy Yu.M. (2008), Modern classifications and standards of treatment of common diseases of internal organs , State Enterprise "DKF", No 4, pp. 30-53.

6. Onishchuk V.E. (2010), "Urgent effect of "endogenous-hypoxic" breathing on spirographic indices in patients with bronchial asthma ",Young Sports Science of Ukraine: Coll. Sciences. works in the field of nat. culture and sports, No 14, pp.145-150.

7. Onishchuk V.E (2011), "Physical rehabilitation of students with bronchial asthma by complex application of the method of "endogenous-hypoxic" breathing and cyclic exercises of aerobic direction», Young Sports Science of Ukraine: Coll. Sciences. works in the field of nat. culture and sports, No 14, pp. 171-177.

8. Furman Yu.M. (2010), "Efficiency of using the method of "endogenous-hypoxic" breathing according to spirographic indices in the system of physical rehabilitation of female students with bronchial asthma», Physical education, sports and health of the nation, No 14, pp. 101-107.

9. Demkina, T. (2015), "Express effect of endogenous-hypoxic breathing on blood pressure and spirography of female students with neurocirculatory dystonia", Physical Education, Sports and Health Culture in Modern Society. No 14, pp. 114-118.

10. Gavrylova Nataliia, Viktoriia Bohuslavska, Maryan Pityn, Yuriy Moseichuk (2017), "Effectiveness of the application of the endogenous-hypoxic breathing technique in the physical training of 13-16-year-old cyclists", Journal of Physical Education and Sport 8 (JPES). No 291, pp. 2568-2575 11. Galandzovskyi, S., Onyshchuk V. (2017), "Improvement of Respiratory System Performance Among the Students of Transport College by Means of Running Exercises and the Method of Endogenous Hypoxic Respiration", Physical Education, Sports and Health Culture in Modern Society.

No (2(38), pp. 75-79

12. Onyshchuk V., Viktoriia B., Maryan P., Oksana K. (2017), "Substantiation of the integrated physical rehabilitation program for the higher educational establishment students suffering from bronchial asthma", Journal of Physical Education and Sport (JPES). No 17(4), pp. 2561-2567. 13. Webb W.R. (1994) "High-resolution computed tomography of obstructive lung disease", Radiol. Clin. North. Amer. No 3, pp. 745-757.

\section{Відомості про авторів / Information about the Authors}

\section{Фурман Юрій Миколайович}

Доктор біологічних наук, професор кафедри медико-біологічних основ фрізичного виховання і фрізичної реабілітації Вінницького державного педагогічного університету.

Фурман Юрий Николаевич

Доктор биологических наук, профессор кафедры медико-биологических основ фризического воспитания и физической реабилитации Винницкого государственного педагогического университета.

Furman Yuriy

Professor of the Department of Medical and Biological Foundations of Physical Education and Physical Rehabilitation, Doctor of Biologica Sciences

E-mail: furman-dok@ukr.net

ORCID:0000-0002-5206-7712.

\section{Онищук Вікторія Євгенівна}

Кандидат наук з фізичного виховання і спорту, доцент кафедри медико-біологічних основ фрізичного виховання і фрізичної реабілітації Вінницького державного педагогічного університету

Онищук Виктория Евгеньевна

Кандидат наук по физическому воспитанию и спорту, доцент кафедры медико-биологических основ физического воспитания и физической реабилитации Винницкого государственного педагогического университета

Onyschuk Victoria Evgenievna PhD

in Physical Education and Sports E-mail:

vitapilgun@yandex.ru

ORCID: 0000-0002-9615-6653.

\section{Гаврилова Наталія Володимирівна}

Кандидат наук з фізичного виховання і спорту, доцент кафедри медико-біологічних основ фрізичного виховання і фрізичної реабілітації Вінницького державного педагогічного університету.

Гаврилова Наталья Владимировна

Кандидат наук по физическому воспитанию и спорту, доцент кафедры медико-биологических основ физического воспитания и физической реабилитации Винницкого государственного педагогического университета.

Gavrilova Natalia Vladimirovna PhD

in Physical Education and Sports E-mail:

gavrilova.natal83@gmail.com; ORCID:

0000-0001-6209-5875.

Здебський Олександр, Магістр

Здебский Александр, Магистр

Zdebski Alexandr

E-mail: Zdebskyi-Sanya@mail.ru

ORCID: 0000-0001-9706-9896. 